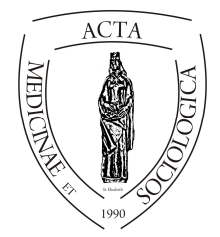

Acta Medicinae et

Sociologica (2020)

UNIVERSITY OF

DEBRECEN

Vol. 11., Különszám. (126-138)

FACULTY OF

HEALTH

doi:

NYÍREGYHÁZA

\title{
Az extrém fizikai aktivitás élettani és immunológiai hatásai
}

\author{
Suhaj Szimonetta ${ }^{1}$, Pócsi István ${ }^{2}$, Csernoch László ${ }^{1}$, Benkő Szilvia ${ }^{1}$ \\ ${ }^{1}$ Élettani Intézet, ÁOK, \\ ${ }^{2}$ Biotechnológiai és Mikrobiológiai Tanszék, TTK, Debreceni Egyetem
}

\begin{tabular}{|c|c|}
\hline INFO & ABSTRACT \\
\hline $\begin{array}{l}\text { Dr. Benkó Szilvia } \\
\text { benkosz@@med.unideb.hu }\end{array}$ & $\begin{array}{l}\text { Abstract. Many researches have proven that prolonged } \\
\text { endurance exercise like long distance running causes acute, } \\
\text { unfavorable effects including damages in kidney, muscu- }\end{array}$ \\
\hline $\begin{array}{l}\text { Keywords: } \\
\text { long distance running, } \\
\text { unfavorable effect, } \\
\text { prevention }\end{array}$ & $\begin{array}{l}\text { loskeletal system, cardiovascular system or gastrointestinal } \\
\text { system. Several attempts were made to prevent or modulate } \\
\text { these unwanted effects. To better understand the physiologi- } \\
\text { cal and immunological background of damages caused by } \\
\text { prolonged endurance exercise, studies were made on } 8 \\
\text { healthy, trained male volunteer during a } 2 \text { hour training } \\
\text { protocol. The protocol included } 1 \text { hour intensive cycling and } \\
1 \text { hour intensive running under medical control. Studies } \\
\text { focused on the measurements of clinical chemistry parame- } \\
\text { ters, also on the global gene expression changes of neutro- } \\
\text { phil granulocytes. Blood samples were collected before } \\
\text { exercise (baseline), and } 3 \text {, } 48 \text { and } 96 \text { hours following exer- } \\
\text { cise. Based on the results, the intensive physical exercise } \\
\text { dramatically changes several parameters in the blood. Many } \\
\text { of these parameters return to the baseline within a few hours, } \\
\text { while many of them requires several days for the recovery. } \\
\text { One of the aims of the future studies is to develop food sup- } \\
\text { plements that may prevent or alleviate the unwanted physio- } \\
\text { logical damages. }\end{array}$ \\
\hline
\end{tabular}

Kulcsszavak:

hosszútávfutás, kedve-

zőtlen hatás, megelőzés

Absztrakt: Számos kutatás bizonyította, hogy a hosszútáv-
futást sajnos számos átmeneti, kedvezötlen hatás is kíséri,
melyek közül a legfontosabbak a vesét, a mozgásszerveket,
valamint a szív- és érrendszert, illetve a gasztrointesztinális
traktust érintő, káros hatások voltak. Orvosi szempontból
lényeges lenne ezeknek a kedvezőtlen hatásoknak a megelö-
zése, enyhítése, illetve modulálása. A testedzés okozta káro-
sodások élettani és immunológiai hátterének pontosabb
megértése érdekében 8 egészséges, edzett, önkéntes férfi
alanyon végeztek egy tanulmányt, melyben egy 2 órás pro-
tokollt követtek. Ez a protokoll 1 óra intenzív kerékpározást,

Absztrakt: Számos kutatás bizonyította, hogy a hosszútávfutást sajnos számos átmeneti, kedvezőtlen hatás is kíséri, melyek közül a legfontosabbak a vesét, a mozgásszerveket, valamint a szív- és érrendszert, illetve a gasztrointesztinális traktust érintő, káros hatások voltak. Orvosi szempontból lényeges lenne ezeknek a kedvezőtlen hatásoknak a megelőzése, enyhítése, illetve modulálása. A testedzés okozta károsodások élettani és immunológiai hátterének pontosabb megértése érdekében 8 egészséges, edzett, önkéntes férfi tokollt követtek. Ez a protokoll 1 óra intenzív kerékpározást, 
valamint 1 óra intenzív futást foglalt magába, folyamatos orvosi ellenőrzés mellett, kontrollált körülmények között. A vizsgálatok a futók klinikai kémiai paraméterei változásának, illetve a neutrofil granulocitákban lezajló globális génexpresszió változásoknak a leírására összpontosulnak. Ezeket a vizsgálatokat közvetlenül a fizikai terhelés előtt („,baseline”), illetve 3, 48 és 96 órával utána végezték. Az eredmények alapján elmondhatjuk, hogy az intenzív sport számos paraméter változását eredményezi, melyek egy része néhány órán belül visszaáll az eredeti alapértékre, számos paraméter viszont csak több nap elteltével áll helyre. A kutatások egyik jövőbeni célja a kedvezőtlen élettani hatások megelőzésére, illetve enyhítésére szolgáló táplálékkiegészítők kifejlesztése.

A publikáció elkészítését a GINOP-2.3.2-15-2016-00062 - "Életminőség fejlesztése KeletMagyarországon" címü projekt támogatta. A projekt az Európai Unió támogatásával, az Európai Regionális Fejlesztési Alap társfinanszírozásával valósult meg.

\section{Bevezetés}

Napjainkban egyre nagyobb teret hódít a hosszútávfutás, melynek egyik legelterjedtebb formája a maratonfutás, a 42195 méter távot magába foglaló futóverseny. Számos pozitív hatása, mint például az állóképesség növelése, az anyagcsere gyorsulása, a tüdőkapacitás növekedése, az erek rugalmasságának fokozása mellett sajnos elég sok kedvezőtlen fiziológiai hatással is jár ez a sportág.

A hosszútávfutást kísérő időleges kedvezőtlen élettani hatásokat már csaknem 40 éve tanulmányozzák. A megfigyelések közül kiemelkedik például a futás alatt bekövetkezö átmeneti vesefunkció zavar, mely föképpen a rabdomiolízissel, azaz a megterhelő fizikai aktivitás következtében kialakult sérüléssel a vázizomsejtekben, a dehidratációval, illetve az ozmolitok csökkent kiválasztásával hozható összefüggésbe (Sanchez és munkatársai 2006). Az egyébként ritkán bekövetkező súlyos vesekárosodás legtöbbször rabdomiolízis, hipernátrémia, fájdalomcsillapítók szedése, hőstressz, illetve vírusos vagy bakteriális infekciók szerencsétlen kombinálódására vezethető vissza (Seedat és munkatársai 1989-1990; Sanchez és munkatársai 2006; Clarkson 2007). A vizelet mikroszkópos vizsgálata a futók 73\%-ban mutatott ki vesetubulus károsodást. A legfrissebb élettani kutatási eredmények arra utalnak, hogy a maratoni futást izomsérülés, időleges vesefunkció csökkenés, illetve hemolízis kísérheti a futás távjának és intenzitásának függvényében (Sanchez és munkatársai 2006). Jól ismertek továbbá a futás alatt bekövetkező hormonális változások, az immunrendszer reakciói, illetve a különböző izomjavító-rendszerek aktiválódása.

Az eddigi vizsgálatok elsősorban a hosszútávfutók klinikai kémiai paraméterek változásainak leírására koncentrálódtak. Rendszerint a következő paramétereket vizsgálták: a vérszérum mioglobin koncentrációját, az immunsejtek számát, típusát és aktiválását, valamint akut vesekárosodás markereket és hormonokat (Neubauer és munkatársai 2013). 
Neubauer és munkatársai által 2013-ban közölt neutrofil granulocitákra vonatkozó tanulmányban a szerzők neutrofil granulocitákban transzkriptom változásokat vizsgáltak DNS-chip technikával és leírták azokat a globális génexpresszió változásokat, melyek az izomsérülések miatt következtek be. Ezeket a transzkriptomikai vizsgálatokat edzett férfi alanyokon, közvetlenül a fizikai terhelés előtt (,baseline”,) illetve 3, 48, és 96 órával utána végezték. A fizikai terhelés kontrollált körülmények között történt (1 óra intenzív szobabicikli +1 óra intenzív futópados futás) folyamatos orvosi ellenőrzés mellett. A résztvevőket mind a terhelés elött, mind pedig utána pontos instrukciókkal látták el például az étkezésre, leginkább a szénhidrát bevitelre vonatkozóan (Neubauer és munkatársai 2013).

A vizsgálatok megállapították a valószínü izomjavítási mechanizmusokat, valamint a veleszületett immunitás génszinten aktivált elemeit is. Kimutatták, hogy a fokozott fizikai terhelés hatására meginduló gyulladási folyamatok átmenetiek, gyorsan lecsengenek, sőt mi több, ezt követően immundepresszív állapot alakulhat ki. Ebben az időszakban fogékonyság figyelhető meg a különböző fertőzésekre, mely jelenség a sportolók körében jól ismert, s aminek a hatékony ellenszerét eddig még nem találták meg (Neubauer és munkatársai 2013).

Az eddigi kutatások célja a sportolókat érő nagy fizikai terhelés nyomán kialakuló génexpressziós szintü változások feltérképezése volt emberi neutrofil granulocitákban, illetve monocitákban, a legkorszerübb teljes RNS szekvenálási módszerek használatával. A további célok között szerepel a gyulladási folyamatok felvázolása, valamint az immundepresszív állapotot eredményező élettani változások modulálási lehetőségeinek a feltárása orvosi szempontból. A hosszútávfutók izomsérüléseinek, kifáradásának, továbbá a futást követő immundepresszív állapotnak a megelőzésére, illetve enyhítésére számos táplálékkiegészítőt kipróbáltak már, de ezek közül eddig egy sem hozott klinikailag megerősített eredményt. Az eddig tesztelt táplálékkiegészítők közé tartoztak az aminosavak, például az elágazó szénláncú aminosavak (glutamin, arginin) aminosav koncentrátum, ill. L-citrullinnal dúsított görögdinnye dzsúsz formájában (Henson és munkatársai 1998). Kipróbáltak ezen kívül különböző antioxidánsokat, E- és C-vitaminokat, N-3 polietilén zsírsavakat, allopurinolt, meggylevet és meggyet, céklalevet, halolajat, rutint, polifenolokat (Areces és munkatársai 2014). Más tanulmányokban szénhidráttal, speciális szénhidrát-protein rúddal és paradicsomlével is próbálkoztak (Clifford és munkatársai 2017). Teszteltek még lecitint, $\beta$-glükánokat, szarvasmarha colostrumot, rózsagyökeret, vasat, metil-szulfonil metánt, de ezek közül egyik sem fejtette ki a várt hatást (Withee és munkatársai 2017).

\section{Vizsgálati protokoll bemutatása}

A vizsgálatokat 8 egészséges, edzett, önkéntes férfi alanyon végezték (Neubauer és munkatársai 2013). A vizsgálati protokoll 1 óra intenzív kerékpározást foglalt magába, melyet 1 óra intenzív futópados futás követett. Több okból is erre a protokollra esett a választás. Egyrészt azért, mert ez a fajta 2 órás fizikai terhelés hasonló hatást vált ki, mint az egyre inkább teret hódító, népszerü triatlon és duatlon versenyek. Másrészt, 
így a kétféle terhelés növekvő mértékü izomsérülés mellett egyre súlyosabb szisztémás gyulladásos választ indukál, ami jelentősebb, mintha csak a kerékpáros terhelést alkalmaznánk önmagában. A 8 résztvevő átlagéletkora $25 \pm 4,1$ év, testtömege 78,6 \pm $7,4 \mathrm{~kg}$, testmagassága a 184,6 $\pm 4,6 \mathrm{~cm}$-t volt, átlagosan heti $6,6 \pm 1,1$ órát sportoltak, és a $\mathrm{VO}_{2}$ max értékük átlagosan $56,3 \pm 6.7 \mathrm{ml} / \mathrm{kg} / \mathrm{min}$ volt, mely a test által maximálisan felvehető és szállítható oxigén mennyiségét adja meg. A vizsgálatban való részvételhez különböző kritériumoknak kellett az önkénteseknek megfelelniük. Fontos volt, hogy ne dohányozzanak, és ne legyen szív- és érrendszeri, légzőszervi, és anyagcserével összefüggő betegségük. A vizsgálat időszaka alatt minden részvevőnek mellőznie kellett a különféle táplálékkiegészítőket, gyógyszereket, gyógyászati készítményeket. Mindemellett igazolniuk kellett, hogy legalább 1 évig rendszeresen sportoltak, beleértve a kerékpározást és a futást a vizsgálatban való részvétel előtt.

Amennyiben a kritériumoknak megfeleltek, egy 6 hetes elöírt edzéstervet kellett követniük a részvevőknek, mely felkészítette őket a protokollban leírt 2 órás fizikai terhelésre, majd a vizsgálatokat megelőző 48 órában kerülniük kellett minden fizikai edzést. A kerékpározást elektronikusan fékezett ergométeres kerékpáron (LodeExcalibur Sport ergométer), a futást pedig motorvezérelt futópadon tették meg 10 km-es időmérési ütemben. A fizikai aktivitás intenzitását Borg-skála segítségével kísérték figyelemmel. A Borg-skála egy tapasztalati skála, amit a sportolón tapasztalható külső jelek (például: izzadás, kipirulás mértéke), illetve a sportoló saját értékelése alapján használnak a terhelés nagyságának megállapítására. Az illető 6-tól (nagyon-nagyon gyenge) 20-ig (nagyon-nagyon erős) értékeli, hogy hogyan éli meg az edzés adta terhelést (fáradás mértékét, fájdalomérzetet) (Borg 1982). Ezen kívül a 8 résztvevőnek egy speciális diétát kellett betartania, amely 9 g szénhidrátot/testsúlykilogramm, 1,4 g fehérjét/testsúlykilogramm, 1,4 g zsírt/ testsúlykilogramm foglalt magába. Ezenkívül kerülniük kellett minden koffein- és alkoholtartalmú készítmény fogyasztását a fizikai terhelés alatt és a mintavételt megelőző 24 órában. A fizikai terhelés reggelén speciálisan elöírt reggelit kellett fogyasztaniuk, mely $2 \mathrm{~g}$ szénhidrátot/testsúlykilogramm tartalmazott. A 2 órás terhelés alatt 3 $\mathrm{ml} /$ testsúlykilogramm $6 \%$ szénhidrát $(60 \mathrm{~g} / \mathrm{l})$ és $2,3 \mathrm{mmol} / 1$ nátrium tartalmú folyadék fogyasztása volt javasolt 15 percenként. 


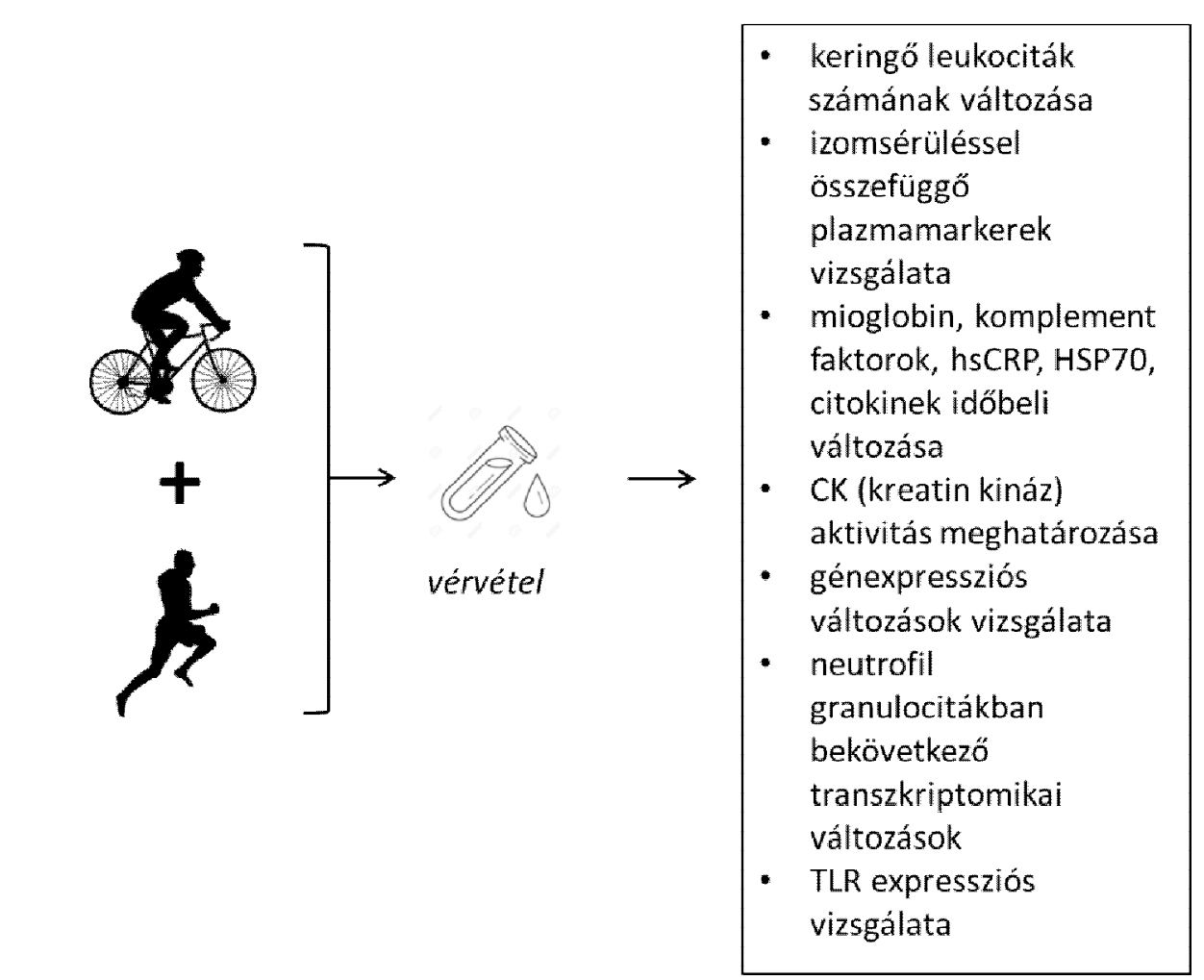

Az ábrához felhasznált képek forrása:https://pixabay.com.

1. ábra. A fizikai terhelést követő vérvétel és a vérmintákból vizsgált paraméterek.

\section{Eredmények}

\section{Általános paraméterek, Borg-skála értékei}

Mind a 8 résztvevő sikeresen teljesítette a 2 órás fizikai terhelést. Az 1 órás kerékpár szakaszban az átlagos teljesítmény $207 \pm 37 \mathrm{~W}$ volt, míg az átlagos sebesség az 1 órás futó szakaszban $11,8 \pm 0,8 \mathrm{~km} / \mathrm{h}$. Az átlagos oxigénfogyasztás a kerékpár szakaszban 40,9 $\pm 7,5 \mathrm{ml} / \mathrm{kg} / \mathrm{min}$, a maximális oxigénfelvétel szintje $\left(\mathrm{VO}_{2} \mathrm{max} \%\right.$-ban $)$ $73,3 \pm 11,0 \%$, az átlagos maximális pulzusszám (az adott egyén maximális terhelésénél mérhető pulzusszám \%-ban) pedig 87,3 \pm 10,3\% volt. Ezzel szemben a futó szakaszban nagyobb értékek születtek, az átlagos oxigénfogyasztásra 48,1 $\pm 5,2$ $\mathrm{ml} / \mathrm{kg} / \mathrm{min}$, a maximális oxigénfelvétel szintjére $\left(\mathrm{VO}_{2} \max \%\right.$-ban) 87,3 $\pm 8,1 \%$, az átlagos maximális pulzusszámra (a maximális terhelésnél mérhető pulzusszám \%ban) pedig 95,0 $\pm 4,4 \%$ volt jellemző.

A fizikai aktivitás intenzitását figyelemmel kísérő Borg-skála értékei már a kezdeti szakasztól kezdve jelentősen megnövekedtek $(\mathrm{P}<0,01)$. Öt perccel a fizika terhelés megkezdése után a kerékpár szakaszban $12 \pm 1$-et, míg a futó szakaszban $14 \pm$ 1-et mutatott ez az érték, mely mind a két esetben kissé erős intenzitásnak felelt meg. A terhelés végére mind a kerékpár, mind a futó szakaszban további növekedést 
tapasztaltak. A kerékpár fázisban $15 \pm 2$-re, a futó fázisban $17 \pm 1$-re növekedett a Borg-skála értéke, mely a kerékpár fázisban erős, a futó fázisban pedig nagyon erös intenzitásnak felelt meg.

\section{Teljes leukocita és a leukocita alcsoportok sejtszámának időbeli változása}

Összességében a keringő leukociták száma jelentős növekedést mutatott a vizsgálatban. Ezek közül a neutrofil granulocitáknál tapasztalták a legjelentősebb növekedést,

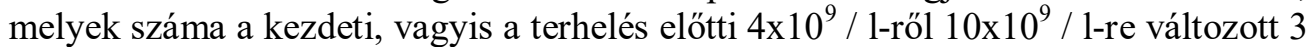
órával a fizikai terhelés teljesítése után $(\mathrm{P}<0,05)$. Ez a növekedés azonban csak átmeneti volt, 48 óra elteltével visszaállt az eredeti, vagyis a terhelés előtti szintre.

\section{Izomsérüléssel összefüggő plazmamarkerek és citokinek időbeli változása}

A mioglobin plazmakoncentrációja 3 órával a terhelés után jelentősen megnövekedett, 50 ng/ml-röl $250 \mathrm{ng} / \mathrm{ml}-\mathrm{re}$, majd 48 óra elteltével, hasonlóan a leukociták számához, visszaállt a terhelés előtti szintjére $(50 \mathrm{ng} / \mathrm{ml})$. Érdekes módon azonban 96 órával a terhelés után újra növekedésnek indult, s végül a kiindulási értéket $47 \%$-kal haladta meg $(\mathrm{P}<0,05)$. A plazma kreatin kináz, CK aktivitás szintén jelentősen megnövekedett 3 órával a 2 órás terhelés után, 180 U/1-ről 350 U/1-re $(\mathrm{P}<0,05)$. A komplement faktorok (C3c, C4), a kortizol, a hsCRP, illetve a HSP70 szintje nem mutatott jelentős időbeli változást a vizsgálat alatt.

A citokinek közül leginkább az IL-1ra, IL-6, illetve az IL-10 plazmakoncentrációja változott jelentősen 3 órával a 2 órás gyakorlat után. Az IL-1ra szintje 310\%-kal $(\mathrm{P}<0,072)$, az IL-6 327\%-kal $(\mathrm{P}<0,01)$ és az IL-10 36\%-kal $(\mathrm{P}<0,05)$ haladta meg a kiindulási értéket, azonban 48 órával a gyakorlat teljesítése után mindhárom interleukin plazmakoncentrációja visszaállt az eredeti, terhelés előtt mért szintjére. Az IL-1 $\beta$ plazmakoncentrációja nem mutatott jelentős időbeli változást a vizsgálat alatt.

\section{GSEA által meghatározott, eltérően expresszálódó géncsoportok}

A GSEA egy olyan bioinformatikai módszer, amellyel az adott két géncsoport finom expressziós különbségei is meghatározhatók. A program a géncsoportok közötti expressziós különbségek alapján egy rangsorolt génlistát készít, a géneket génexpressziós értékük alapján sorrendbe állítja. A génlista a legnagyobb mértékben indukált és a legnagyobb mértékben represszált géneket egyaránt tartalmazza (Subramanian 2005). A gének különböző adatbázisokból (Molecular Signatures Databse, Biocarta, Reactome, KEGG) származtak, melyek kiértékelése és rangsorolása a t-teszt alkalmazásával történt, $\mathrm{P}<0,05$ szignifikancia szint megválasztásával

Ezen módszer alapján, 3 órával a fizikai terhelés után indukciót mutattak például a következő géncsoportok: IL-1 receptor útvonalat kódoló gének (Biocarta; $\mathrm{P}<0,023$ ), illetve a Toll-like receptor (TLR) útvonalat kódoló gének (KEEG; $\mathrm{P}<0,029)$. Repressziót mutattak például az alábbi géncsoportok: a transzlációért felelős gének (Reactome; $\mathrm{P}<0,0001$ ), az aminoaciltRNS bioszintéziséért felelős gének (KEEG; $\mathrm{P}<0,0001$ ), a peptidlánc elongácójáért felelős gének (Reactome; $\mathrm{P}<0,001$ ), a riboszómát kódoló gének (KEGG; $\mathrm{P}<0,001)$, az RNS metabolizmusát kódoló gének (Reactome; $\mathrm{P}<0,006$ ), az inzulin szintézisért és szekrécióért felelős gének (Reactome; $\mathrm{P}<0,012$ ), az RNS polimeráz III transzkripciót kódoló gének 
(Reactome; $\mathrm{P}<0,030)$, illetve az RNS polimeráz III transzkripció iniciációjáért felelős gének (Reactome; $\mathrm{P}<0,048$ ) (Neubauer és munkatársai 2013).

A fizikai terhelés után 48 órával repressziót mutatott például a mitokondirumot kódoló gén $(\mathrm{P}<0,024), 96$ órával a terhelés után pedig mindössze 3 géncsoport volt represszálva: így a tRNS aminoacilációért felelős gének (Reactome; $\mathrm{P}<0,009$ ), a ZAP70 transzlációjáért felelös gének (Reactome; $\mathrm{P}<0,009$ ), valamint az aminoaciltRNS bioszintéziséért felelős gének (KEGG; $\mathrm{P}<0,009)$.

\section{qRT-PCRvizsgálatok eredménye}

A DNS-chip vizsgálat alapján a szignifikáns eltérést mutató géncsoportok azonosítása után 6 gén expresszióját validálták qRT-PCR módszer segítségével. A 6 gén közé tartozott az IL-1R1, az IL-1RN, az IRAK3, a TLR4, a CCL5 és a GNLY. Az IL-1R1 expressziós szintje 5,2-szeresére $(\mathrm{P}<0,05)$, az IL-1RN expressziós szintje 5,8szorosára $(\mathrm{P}<0,05)$, az IRAK3 expressziós szintje 2-szeresére $(\mathrm{P}<0,05)$, míg a TLR4 expressziós szintje 2,9-szeresére növekedett $(\mathrm{P}<0,05) 3$ órával a fizikai terhelés után. A CCL5 expressziós szintje 0,3 -szorosára csökkent $(\mathrm{P}<0,05) 3$ órával a fizikai terhelés után, a GNLY pedig nem mutatott jelentős változást a vizsgálat során. A 6 gén közül egyik sem mutatott jelentős változást 48, illetve 96 órával a fizikai terhelést követően.

\section{A neutrofil granulocitákban bekövetkező transzkriptomikai változások}

A neutrofil granulociták száma az IL-6 és az IL-10 interleukinek koncentrációjával együtt jelentősen megnövekedett $(\mathrm{P}<0.05) 3$ órával a fizikai terhelés után. A neutrofil granulociták száma 48 órával a terhelés után visszaállt az eredeti, normális szintre, ezzel bizonyítva, hogy a kezdeti gyulladáskeltő válasz csak átmeneti volt, és gyorsan lecsengett. A keringő neutrofil granulociták számának ennyire jelentős növekedéséhez hozzájárulnak a szisztémásan felszabaduló citokinek: például az IL-6 és a stresszhormonok, a katekolaminok. A neutrofil granulociták tökéletesen alkalmasnak bizonyultak a veleszületett immunitás tanulmányozására, ugyanis szoros kapcsolatban állnak a 2 órás fizikai terhelés által kiváltott izom és szisztémás gyulladási folyamatokkal.

\section{TLR transzkripciós aktivitása neutrofil granulocitákban}

Az IL-R1 és a TLR mintázatfelismerök szorosan összefüggnek a veleszületett immunitással, ugyanis hasonló jelátviteli kaszkádokat indukálnak. Az általuk aktivált közös útvonalak közé tartozik például a nukleáris faktor kappa B (NF- $\mathrm{B})$ transzkripciós faktor útvonala, mely a gyulladáskeltő citokinek és kemokinek indukcióját eredményezi (Chen és Nunez 2010). A stressz, illetve a sérült sejtek hatására megjelenő szövetalkotók, fragmentumok és endogén molekulák a neutrofil granulociták által kerülnek felismerésre a keringésben, mely a következő gének indukcióját okozza 3 órával a fizikai terhelés után: TLR1 $(\mathrm{P}<0,016)$, TLR4 $(\mathrm{P}<0,022)$, TLR6 $(\mathrm{P}<0,008)$, TLR8 $(\mathrm{P}<0,034)$ (Chen és Nunez 2010).

Különböző fertőző mikroorganizmusok is szerepet játszhatnak a TLR útvonal transzkripciós aktiválásában, például: a 2 órás fizikai terhelés bél iszkémiát indukálhat, ugyanis hőstressz hatására a bélben lévő káros, endotoxint termelő baktériumok elszaporodhatnak, és a toxinok a véráramba kerülhetnek. Ezt a jelenséget egy 
hosszútávú triatlonon figyelték meg extrém forró időjárási viszonyok között (Jeukendrup és munkatársai 2000). További lehetséges steril gyulladási szignálok lehetnek a 2 órás fizikai terhelés következtében megemelkedett szintü endogén nukleinsavak, melyek úgyszintén kapcsolatban állnak a TLR receptorokkal. Ide tartoznak többek között a keringő sejtmentes DNS-ek, a szabad zsírsavak, illetve a hősokkproteinek, közülük is a HSP70 családba tartozó HSP72. Az IL-1R-hez kapcsolódó megváltozott expressziójú gének a következők voltak: IL-1ra (IL-1RN) $(\mathrm{P}<0,005)$, a MAPK14 $(\mathrm{P}<0,010)$, IL-1 $\beta(\mathrm{P}<0,024)$ és az NF- $\kappa \mathrm{B}$ aktivációért felelős gének. - További, úgynevezett reprezentatív, idegen szervezeteket, organizmusokat reprezentáló gének expressziója változott meg, melyek szintén hozzájárultak a vizsgált géncsoportok kifejeződésében megfigyelhető koordinált változásokhoz. Ide tartoztak például a következő gének: az S100A12 ( $<<0,006)$, CAMP $(\mathrm{P}<0012)$, és az IFNGR2 $(\mathrm{P}<0,022)$.

\section{Élettani hatások}

A maratonfutás, mint a hosszútávfutás egyik legjelentősebb formája, számos élettani hatást eredményez, ami kihathat a mozgás szervrendszerére, a gasztrointesztinális traktusra, a szív- és érrendszer egészségére és nem utolsó sorban a kiválasztó szervrendszerre.

\section{A mozgás szervrendszerét érintő élettani hatások}

A hosszútávfutás következtében a futók eltérő mozgásszervi problémákról számoltak be, melyek között a legelterjedtebbek az izomgörcsök, vízhólyagok, akut bokaés térdsérülések voltak. Ez utóbbiak sokkal elterjedtebbnek bizonyultak a közúton tartott versenyeken (Sanchez és munkatársai 2006). A versenyre való felkészülés, az edzés mennyisége szoros összefüggésben állt a kialakult sérülések számával. Egy versenyző minél többet készült, edzett a versenyre, annál kisebb eséllyel jelentkeztek nála a mozgásszervi problémák (Macera 1992).

\section{Gasztrointesztinális hatások}

A futók nagy részénél jelentkeztek gasztrointesztinális tünetek a futás alatt. Az enyhébb puffadástól, hasi görcsöktől, hányingertől, hányástól és széklet visszatartási problémáktól kezdve a súlyos iszkémiás vastagbélgyulladásig (Riddoch és munkatársai 1988). Ezekért a tünetekért a bél vérellátásának akadályozottsága lehet a felelős. Egy tanulmányban a futók 16\%-a számolt be véres hasmenésröl legalább egyszer a hosszútávfutás után, melyért a belek futás által kiváltott mechanikai sérülése, valamint a mezenteriális iszkémia lehetett a felelős (Sullivan és Wong 1992). A véres bélmozgások növelhetik az iszkémiás vastagbélgyulladás és a véres gyomornyálkahártya-gyulladás tüneteit. A gyomorsav és pepszin termelődését csökkentő gyógyszer, melyet leginkább gyomor- és nyombélfekély esetén használnak, a Cimetidin használata a verseny elött, illetve alatt csökkentheti a vér megjelenését a székletben. Az NSAID, a nem szteroid gyulladáscsökkentök, illetve az enyhe és közepes fájdalmak esetén alkalmazható szintén nem szteroid gyulladáscsökkentő és fájdalomcsillapító gyógyszer, az Aspirin használata viszont növelheti a belek áteresztőképességét, ezzel a gasztrointesztinális tünetek megjelenését (Sanchez és munkatársai 2006). Ezenkívül fontos számolni az adott környezeti hatásokkal, 
ugyanis a dehidratációból származó hipervolémia is szerepet játszhat a tünetek kialakulásában (Sanchez és munkatársai 2006).

\section{Szív- és érrendszeri hatások}

A fizikai terhelés különböző veleszületett, illetve szerzett szív- és érrendszeri betegségeket fedhet fel. Egy tanulmányban, melyben sportolók és nem sportolók körében vizsgálták a serdülőknél és a fiatal felnőtteknél (12-35 év közötti korosztály) bekövetkező hirtelen haláleseteket bebizonyították, hogy a sportolók nagyobb gyakorisággal lesznek ennek áldoztai. Ez szorosan összefügg a veleszületett szív- és érrendszeri betegségekkel, koszorúér rendellenességekkel, szívritmuszavarral, kardiomiopátiával és a koszorúér idő előtti megbetegedéseivel (Corrado és munkatársai 2003). Egy tanulmány során, melyben szintén a fiatal sportolók körében vizsgálták a hirtelen bekövetkező haláleseteket, bebizonyították, hogy a legelterjedtebb azonosított betegség a szívfal izomzatának megvastagodásával, gyengeséggel, mellkasi fájdalommal, nehézlégzéssel járó hipertrófiás kardiomiopátia volt, ami az esetek 21,5\%-ban a koszorúér rendellenességeknek volt tulajdonítható (Maron és munkatársai 1996). A tünetek megjelenését különböző tényezők súlyosbíthatják, mint például a dohányzás, a magas vérnyomás, a magas koleszterinszint és a betegség családon belüli nagy előfordulási gyakorisága. Azok a sportolók, akik nem készülnek fel rendesen, nem edzenek rendszeresen a hosszútávfutásra, 56-szor nagyobb kockázatát hordozzák a hirtelen bekövetkező halálnak (Siscovick és munkatársai 1984).

\section{Hiponátrémia}

Az elektrolitokkal összefüggő hiponátrémia elég gyakori velejárója a maratoni futóversenyeknek, melynek tünetei az enyhe görcsöktől, szédüléstől, gyengeségtől egészen a mentális zavarig, agyi és tüdőödémáig, kómáig, illetve ritkán halálig terjedhetnek (Sanchez és munkatársai 2006). A fizikai aktivitás által indukált hiponátrémiának 3 különböző mechanizmusát ismerjük. Az egyik az, hogy a sportolók vizet, illetve elektrolitokat veszítenek futás közben az izzadás következtében, a folyadékpótlással viszont csak a vízveszteséget lehet helyreállítani, a megfelelö $\mathrm{Na}^{+}$, és a többi elektrolit élettani koncentrációját sajnos nem. Másik mechanizmusa a hiponátrémia kialakulásának a folyadék-túlterhelés, tehát a sportolók több folyadékot fogyasztanak, mint amit a futás alatt elveszítenek, és emiatt a fokozott hidratáltság jellemzi őket. Ilyen esetben a testtömegük is meghaladja a futás elött mért testtömegüket (Davis és munkatársai 2001). Végül a harmadik mechanizmus, ami a nem megfelelő folyadék-visszatartás következtében alakul ki, ezt az állapotot az aldoszteron és vazopresszin, más nevén az antidiuretikus hormon (ADH) normál tartománytól eltérő szintje is eredményezheti (Hew és munkatársai 2003). Különböző más tényezők is befolyásolhatják a hiponátrémia kialakulását. Ilyen tényező például a hőmérséklet, a páratartalom, a sportolók neme, testtömegük, illetve fiziológiás különbségeik (Sanchez és munkatársai 2006; Clarkson 2007). Egy tanulmányban 488 maratoni futót vizsgáltak meg és közvetlen a futás után a futók 13\%-ánál jelentkezett hiponátrémia $\left(\left[\mathrm{Na}^{+}\right]=135 \mathrm{mmol} / \mathrm{L}\right), 0,6 \%$-ánál pedig súlyos kritikus hiponátrémia $\left(\left[\mathrm{Na}^{+}\right]=120 \mathrm{mmol} / \mathrm{L}\right)$ (Sharwood és munkatársai 2002). 


\section{A vesét érintő élettani hatások}

A fizikai terhelés által kiváltott vese diszfunkció a tünetmentes állapottól kezdve, a hematúrián keresztül az akut veseelégtelenségig megjelenhet, ugyanis amikor a terhelés intenzitása meghaladja a $\mathrm{VO}_{2} \max 50 \%$-át, a vese vérárama, a glomeruláris filtrációs ráta, a $\mathrm{Na}^{+}$kiválasztása, illetve a vizelet áramlási sebessége jelentősen lecsökken (Van Zyl-Smit és munkatársai 2000). A futók gyakran számolnak be hematúriáról, tehát vérről a vizeletükben a megeröltető futás után, ami leggyakrabban vese, de lehet húgyvezeték, húgyhólyag, illetve húgycső eredetü is. Szerencsére akut veseelégtelenség ritkán alakul ki a futók körében, akiknél pedig kialakul, szoros összefüggésben áll a már korábban említett rabdomiolízissel. Mint korábban említettük, a megterhelö fizikai aktivitás sérülést eredményezhet a vázizomsejtekben, s ezt az összetett folyamatot nevezik rabdomiolízisnek. A legtöbb esetben ez a sérülés következmények nélkül regenerálódik, azonban, ha a sérülés mély, az izomfehérjék a véráramba kerülhetnek. Az egyik legjelentősebb ilyen fehérje a már korábban is sokszor említett mioglobin, ami nagy koncentrációban és bizonyos körülmények között, például hőstressz és dehidratáció esetén, képes leülepedni a vesetubulusokba, ezzel akut veseelégtelenséget létrehozva (Clarkson 2007). A legújabb tanulmányok bebizonyították, hogy a vérszérum izomfehérjéinek koncentrációja jelentősen megnövekedett egy kitartó fizikai terhelés következtében anélkül is, hogy az veseelégtelenséget eredményezett volna, ugyanis ennek a kialakulásában egyéb, már korábban is említett faktorok (hőstressz, dehidratáció) is szerepet játszanak. Az akut veseelégtelenség kialakulásának kockázatát különböző gyógyszerek, fájdalomcsillapítók szedése, illetve a futók verseny előtti kedvezőtlen egészségügyi állapota is növelheti (Clarkson 2007).

MacSearraigh és munkatársai, (1979) a Dél-Afrikában megrendezett Comrades Marathonon 9 akut veseelégtelenségben szenvedö esetet jelentettek, melyböl 7-en fájdalomcsillapítót szedtek, illetve 4-en szenvedtek valamiféle bakteriális vagy vírus okozta fertőzésben. Seedat et al. (1989) további 4 esetet jelentett szintén ezen a versenyen, melyből kettő esetén a futóknak valamilyen fertőzése volt a versenyt megelőzően, illetve mind a 4 esetben a versenyzők valamilyen fájdalomcsillapítót vettek be a verseny napján.

Vitting és munkatársai, egy 41-éves férfi esetét jelentették, aki fájdalom és lázcsillapításra, illetve gyulladásos betegségek kezelésére alkalmazható nem-szteroid gyulladáscsökkentő gyógyszert, úgynevezett Naproxént szedett 1 héten keresztül a versenyt megelőzően. Sajnos már a verseny elején kiesett súlyos görcsök, hányinger és láz következtében, 2 nappal később pedig akut veseelégtelenséget állapítottak meg nála is. Még nincs rá bizonyíték, hogy valóban ez a gyógyszer játszott-e közre a veseelégtelenség kialakulásában, de mindenesetre kerülendő a használata a verseny során (Sanchez és munkatársai 2006).

\section{Összefoglalás}

Mint ahogy azt már korábban is említettük, manapság egyre nagyobb teret hódít a hosszútávfutás, melynek hatásait már hosszú évek óta tanulmányozzák a kutatók. Az 
eddigi vizsgálatok alapján kijelenthetjük, hogy a hosszútávfutás kedvező élettani hatásait, sajnos számos kedvezőtlen élettani hatás is kíséri, melyek közül kiemelkednek a vesét, a mozgásszerveket, valamint a szív- és érrendszert, illetve a gasztrointesztinális traktust érintő hatások (Sanchez és munkatársai 2006).

A fentiekben említettek megelőzésére, enyhítésére, számos táplálékkiegészítő, vitamin, illetve antioxidáns került már kipróbálásra, de sajnos eddig még egyik sem hozott klinikailag megerősített hatást.

Mivel ez az egyre inkább népszerübbé váló sportág számos embert, sportolót érint további kutatásokra lenne szükség, hogy ezek a problémák mihamarabb orvoslásra kerüljenek.

\section{Felhasznált irodalom}

1. Areces, F., Salinero, J.J., Abian-Vicen, J., González-Millán, C., Gallo-Salazar, C., Ruiz-Vicente, D., Lara, B., Del Coso, J. (2014): A 7-day oral supplementation with branched-chain amino acids was ineffective to prevent muscle damage during a marathon. Amino acids, 46: 1169-1176. DOI: https://doi.org/10.1007/s00726-014-1677-3

2. Borg, G.A. (1982): Psychophysical bases of perceived exertion. Med Sci Sports Exerc, 14: 377-81. DOI: https://doi.org/10.1249/00005768-198205000-00012

3. Chen, G.Y., Nunez, G. (2010): Sterile inflammation: sensing and reacting to damage. Nat Rev Immunol, 10: 826-837. DOI:

https://doi.org/10.1038/nri2873

4. Clarkson, P.M. (2007): Exertional rhabdomyolysis and acute renal failure in marathon runners. Sports Med, 37: 361-363. DOI:

https://doi.org/10.2165/00007256-200737040-00022

5. Clifford, T., Allerton, D.M., Brown, M.A., Harper, L., Horsburgh, S., Keane, K.M., Stevenson, E.J., Howatson, G. (2017): Minimal muscle damage after a marathon and no influence of beetroot juice on inflammation and recovery. Applied Physiology, Nutrition, and Metabolism, 42: 263-270. DOI: https://doi.org/10.1139/apnm-2016-0525

6. Corrado, D., Basso, C., Rizzoli, G., Schiavon, M., Thiene, G. (2003): Does sports activity enhance the risk of sudden death in adolescents and young adults? J Am Coll Cardiol, 42: 1959-1963. DOI:

https://doi.org/10.1016/j.jacc.2003.03.002

7. Davis, D.P., Videen, J.S., Marino, A., Vilke, G.M., Dunford, J.V., Van Camp, S.P., Maharam, L.G. (2001): Exercise-associated hyponatermia in marathon runners: a two-year experience. J Emerg Med, 21: 47-57. DOI: https://doi.org/10.1016/s0736-4679(01)00320-1

8. Henson, D.A., Nieman, D. C., Parker, J.C., Rainwater, M.K., Butterworth, D.E., Warren, B.J., Utter, A., Davis, J.M., Faqoaqa, O.R., Nehlsen-Cannarella, S.L. (1998): Carbohydrate supplementation and the lymphocyte proliferative response to long endurance running. Int J Sports Med, 19: 574-580. DOI: https://doi.org/10.1055/s-2007-971962 
9. Hew, T.D., Chorley, J.N., Cianca J.C., Divine, J.G. (2003): The incidence, riskfactors, and clinical manifestations of hyponatermia in marathon runners. Clin J Sport Med, 13: 41-47. DOI: https://doi.org/10.1097/00042752-200301000-00008

10. Jeukendrup, A.E., Vet-Joop, K., Sturk, A., Stegen, J.H., Senden, J., Saris, W.H., Wagenmakers, A.J. (2000): Relationship between gastro-intestinal complaints and endotoxaemia, cytokine release and the acute-phase reaction during and after a long-distance triathlon in highly trained men. Clin Sci (Lond), 98: 47-55. DOI: https://doi.org/10.1042/cs19990258

11. Macera, C.A. (1992): Lower extremity injuries in runners, advances in prediction. Sports Med, 13: 50-57. DOI: https://doi.org/10.2165/00007256199213010-00005

12. MacSearraigh, E.T., Kallmeyer, J.C., Schiff, H.B. (1979): Acute renal failure in marathon runners. Nephron, 24: 236-240. DOI:

https://doi.org/10.1159/000181723

13. Maron, B.J., Shirani, J., Poliac, L.C., Mathenge, R., Roberts, W.C., Mueller, F.O. (1996): Sudden cardiac death in young competitive athletes. Clinical, demographic and pathological profiles. JAMA, 276: 199-204. DOI: https://doi.org/10.1001/jama.1996.03540030033028

14. Neubauer, O., Sabapathy, S., Lazarus, R., Jowett, J.B.M., Desbrow, B., Peake, J.M., Cameron-Smith, D., Haseler, L.J., Wagner, K-H., Bulmer, A.C. (2013): Transcriptome analysis of neutrophils after endurance exercise reveals novel signaling mechanisms in the immune response to physiological stress. J Appl Physiol, 114: 1677-1688. DOI: ttps://doi.org/10.1152/japplphysiol.00143.2013

15. Riddoch, C., Trinick, T. (1988): Gastrointestinal disturbances in marathon runners. Br J Sports Med, 22: 71-74. DOI: https://doi.org/10.1136/bjsm.22.2.71

16. Sanchez, L.D., Corwell, B., Berkoff, D. (2006): Medical problems of marathon runners. Am J Emerg Med, 24: 608-615. DOI:

https://doi.org/10.1016/j.ajem.2006.01.023

17. Seedat, Y.K., Aboo, N., Naicker, S., Parsoo, I. (1989): Acuterenal failure in the "Comrades Marathon" runners. Ren Fail, 11: 209-212. DOI: ttps://doi.org/10.3109/08860228909054933

18. Sharwood, K., Collins, M., Goedecke, J., Wilson, G., Noakes, T. (2002): Weight changes, sodium levels and performance in the South African IronmanTriathlon. Clin J Sport Med, 12: 391-399 DOI: https://doi.org/10.1097/00042752-200211000-00012

19. Siscovick, D.S., Weiss, N.S., Fletcher, R.H., Lasky, T. (1984): The incidence of primary cardiac arrest during vigorous exercise. N Engl J Med, 311: 874-877. DOI: https://doi.org/10.1056/nejm198410043111402

20. Sullivan, S.N., Wong, C. (1992): Runners' diarrhea. Different patterns and associated factors. J Clin Gastroenterol, 14: 101-104. DOI: https://doi.org/10.1097/00004836-199203000-00005

21. Subramanian, A., Tamayo, P., Mootha, V.K., Mukherjee, S., Ebert, B.L., Gillette, M.A., Paulovich, A., Pomeroy, S.L., Colub, T.R., Lander, E.S., Mesirov, J.P. (2005): Gene set enrichment analysis: a knowledge-based approach for 
interpreting genome-wide expression profiles. Proc Natl Acad Sci U S A, 102: 15545-15550. DOI:

https://doi.org/10.1073/pnas.0506580102

22. Van Zyl-Smith, R., Mills, P., Vogelpoel, L. (2000): Case report: unrecognized acute renal failure following the Comrades Marathon. S Afr Med J, 90: 39-40.

23. Vitting, K.E., Nichols, N.J., Seligson, G.R. (1986): Naproxen and acute renal failure in a runner. Ann Intern Med, 105: 144. DOI:

https://doi.org/10.7326/0003-4819-105-1-144_1

24. Withee, E.D., Tippens, K.M., Dehen, R., Tibbitts, D., Hanes, D., Zwickey, H. (2017): Effects of Methylsulfonylmethane (MSM) on exercise-induced oxidative stress, muscle damage, and pain following a half-marathon: a doubleblind, randomized, placebo-controlled trial. J Int Soc Sports Nutr, 14: 24. DOI: https://doi.org/10.1186/s12970-017-0181-z 